\title{
Center for Grundtvig-Studier - de første 20 år
}

\author{
Jens Holger Schjørring
}

\section{Baggrund}

Siden Det Teologiske Fakultet i Aarhus blev oprettet i 1942, havde der blandt dets professorer været flere, der gjorde sig gældende som Grundtvigforskere. Regin Prenter havde været med i Grundtvig-Selskabet fra dets grundlæggelse og havde bl.a. skrevet en programmatisk artikel i første årgang af selskabets årbog, "Grundtvigs syn på forkyndelsen", GrundtvigStudier 1948. Både i Prenters undervisning på fakultetet og i hans betydelige dogmatik "Skabelse og genløsning" spillede Grundtvig en afgørende rolle. Poul Georg Lindhardt fokuserede i sin forskning i efterkrigsperioden på de folkelige vækkelser i det 19. århundrede, samtidig med at han skrev om Grundtvig og Kierkegaard som de to fremtrædende personer. Lindhardts udforskning af vækkelsestraditionen blev taget op og videreført af Anders Pontoppidan Thyssen, der i 1958 skrev doktordisputats om Den nygrundtvigske bevagelse og efterfølgende blev leder af et stort anlagt forskningsprojekt om vækkelsernes frembrud i Danmark. Samtidig fremlagde Pontoppidan Thyssen indgånde studier af Grundtvig. Ikke mindst hans opposition ved Kaj Thanings disputats i 1963 havde karakter af et selvstændigt forskningsbidrag. Da Christian Thodberg tiltrådte som professor i 1973, videreførte han på selvstændig måde traditionen, idet han holdt øvelsesundervisning om Grundtvigs salmer og prædikener. Disse øvelser blev i sjælden grad igangsættende for mange studerende, hvilket bl.a. viste 
sig i bogen For sammenhengens skyld. Ord og motiver i Grundtvigs salmer og pradikener (1977), der samtidig udgjorde Grundtvig-Studier 1977.

Dertil kom, at der ved universitetets humanistiske fakultet var fremtrædende Grundtvigforskere, først og fremmest Gustav Albeck og William Michelsen, der begge havde taget del i Grundtvig-Selskabet siden grundlæggelsen. Endvidere var biskoppen i Århus Stift fra 1963-1979, Henning Høirup, Grundtvigforsker. Han havde som den første i landet skrevet disputats om Grundtvig, Grundtvigs syn på tro og erkendelse (1949).

\section{Centerets tilblivelse}

Med historisk baggrund i denne tradition henvendte daværende dekan ved Det Teologiske Fakultet, Kirsten Nielsen, sig i 1988 til Christian Thodberg og mig og tilbød os en startkapital på 200.000 kr., hvis vi ville tage initiativ til et fremstød inden for Grundtvigforskningen. Vi behøvede ikke lang betænkningstid, inden vi sagde ja tak og begyndte at drøfte indledende praktiske skridt. Det stod fra første færd klart, at det hele måtte bygges op omkring fakultetets to koryfæer inden for Grundtvigforskningen, Christian Thodberg og Anders Pontoppidan Thyssen. Sammen havde de to redigeret bogen Grundtvig og grundtvigianismen i nyt lys. Hovedtanker og udviklingslinier fra de senere års Grundtvigforskning, der blev udgivet af Det Danske Selskab i forbindelse med Grundtvigjubilæet i 1983 og blev oversat til engelsk, tysk og fransk. Endvidere havde de hver for sig publiceret betydelige bøger og artikler, der nød anerkendelse i alle kredse. Jeg havde gennem nogle år holdt øvelser sammen med Thodberg og i 1987 udgivet bogen Grundtvig og påsken. Vi enedes straks om en rollefordeling, der indebar, at Thodberg skulle videreføre sit arbejde med Grundtvigs syn på kirke og gudstjeneste med særligt henblik på salmer og prædikener. Thyssen skulle fortsætte sit arbejde med Grundtvig og grundtvigianismen i historisk perspektiv, mens jeg skulle søge at sætte Grundtvig i forhold til teologiske positioner i historie og nutid. Som noget af det første blev der taget initiativ til udgivelse af nogle af Thodbergs betydeligste afhandlinger i anledning af hans 60-års dag i 1989, nu samlet i bogen Syn og sang. Poesi og teologi hos Grundtvig, afhandlinger af Christian Thodberg, red. af Henrik Glahn, Søren Sørensen, Anders Pontoppidan Thyssen og Jens Holger Schjørring. På lignende måde udsendtes i anledning af Thyssens 70 -års 
dag i 1991 et udvalg af hans væsentligste afhandlinger samlet i bogen Grundtvig og den grundtvigske arv. Afhandlinger af Anders Pontoppidan Thyssen, udg. af Jakob Balling, Hans Raun Iversen, Jens Holger Schjørring og Christian Thodberg. Det var endvidere et led i rollefordelingen, at Thodberg og Thyssen skulle have mest mulig tid til deres forskning, mens jeg som junior i gruppen skulle forestå den praktiske koordinering.

En del af det bevilgede starttilskud anvendte vi til indkøb af antikvariske bøger til supplement af de bøger, vi allerede disponerede over, med henblik på opbygning af et selvstændigt Grundtvigbibliotek ud over de allerede eksisterende institutsamlinger. Endvidere stod det højt på Thodbergs $ø$ nskeliste at indkøbe mikrofilm af alle utrykte manuskripter i Grundtvigarkivet på Det Kongelige Bibliotek, således at de kunne studeres ved et læseapparat også på biblioteket i Aarhus. Desuden ansatte vi en sekretær på timelønsbasis, stud.theol. Margrethe Koch, der stod bi med praktisk assistance i den indledende fase. Dernæst indbød vi til et planlægningsmøde sammen med de Grundtvigeksperter, som vi i særlig grad ønskede at samarbejde med, eftersom det fra første færd var vores ambition, at arbejdet skulle gribes tværfagligt og internationalt an. Derfor samledes vi i januar 1989 til et møde over to dage i Aarhus, hvori deltog en række kolleger, der repræsenterede litteraturhistorie, almen historie, skolehistorie og pædagogik, højskoleverdenen o.a. Samtidig havde vi inviteret kolleger fra Norge, Sverige, England og Tyskland. Det var indlysende, at der skulle tages hensyn til den store interesse for Grundtvigs skoletanker, historisk og aktuelt, men det var lige så klart, at dette ikke måtte ske på bekostning af de øvrige relevante fagområder, heller ikke de kirkelige og teologiske.

\section{Den engelske forbindelse}

På mødet var der bred tilslutning til ønsket om at styrke bestående samarbejdsrelationer, udforme nye forskningsinitiativer samt i særlig grad at understrege den internationale dimension. Det stod os klart, at der uden for landets grænser fandtes en del Grundtvigforskere, der arbejdede inden for flere forskellige fagområder, men det var oplagt, at der var behov for koordination og støtte fra dansk side. Drøftelserne førte til skitsering af et konkret projekt, "Grundtvig og England", fordi dette emne skønnedes at give plads for såvel det tværfaglige som det internationale per- 
spektiv. Da jeg i de følgende måneder alligevel skulle på nogle måneders forskningsophold i England, fik jeg i opdrag i samarbejde med Arthur Macdonald Allchin at tage kontakt til engelske kolleger, der var villige til at deltage i projektet. Det lykkedes at få tilsagn fra en række kolleger fra forskellige kirke- og universitetssammenhænge i England, der sammen med en tilsvarende kreds af personer fra Danmark kunne indlede studier om Grundtvig, således at perspektivet blev en dialog hen over Nordsøen.

Gruppen samledes til et første arbejdsmøde på Aarhus Universitets kursusejendom Sandbjerg Kursuscenter i april 1990, og arbejdet fortsatte med et tilsvarende møde i Durham, England, i april 1991. Resultatet af drøftelserne blev et udkast til en publikation, der efter en krævende skrive- og redaktionsfase kunne fremlægges i bogen Heritage and Prophecy. Grundtvig and the English-speaking World (1994, udgivet i både England og Danmark). I bogen indgår en historisk introduktion til Grundtvig samt en række emneområder, der belyses i dialogform, idet en engelsk og en dansk bidragyder belyser samme emneområde, f.eks. Grundtvig og den oldengelske digtning, Grundtvig og samtidens litteratur, Grundtvigs salmedigtning i relation til engelsk og dansk salmehistorisk tradition, Grundtvigs tanker om skole og samfund samt en væsentlig tilføjelse: Grundtvig og den såkaldte tredje verden i moderne historie. Sidstnævnte perspektiv viste sig i de følgende år særlig betydningsfuldt. Bogen kunne ikke være blevet til, hvis vi ikke havde fået bistand af tre engelske kolleger, der alle var særdeles kyndige og samtidig beherskede dansk, Kenneth Stevenson, S.A.J. Bradley og A.M. Allchin. Desuden var der behov for kompetent sekretærbistand, hvilket fra dansk side blev ydet af cand.theol. Susanne Gregersen, der i nogle år var ansat på deltid som videnskabelig medarbejder ved centeret. Samtidig med at der blev satset på dette projekt, blev det besluttet at opfordre den allerede nævnte engelske historiker, teolog og præst Arthur Macdonald Allchin til at skrive en almen indføring på engelsk. Allchin havde gennem en årrække besøgt venner og bekendte i Danmark og havde efterhånden udbygget sit kendskab til Grundtvig så meget, at han havde læst store dele af forfatterskabet på dansk og ligeledes havde skaffet sig et indgående alment kendskab til dansk kirkeliv, kultur- og samfundstradition. Da han havde holdt talrige foredrag, vidste vi, at han kunne beskrive komplicerede kirkelige og teologiske problemstillinger, så de blev føjet ind $\mathrm{i}$ en alment tilgængelig form, og vi vidste tillige, at han mestrede en i bedste forstand populær fremstillingsform og 
kunne skrive på et smukt engelsk, som ingen dansker nogen sinde ville kunne matche. Som anerkendelse for sine fortjenester blev Allchin i 1991 gjort til æresdoktor ved Aarhus Universitet. I de følgende år fortsatte han sit arbejde med bogen, der udkom i 1997 med titlen N.F.S. Grundtvig. An Introduction to his Life and Work. Inden udgivelsen var manuskriptet blevet omhyggeligt redigeret ved Elisabeth Glenthøj. Bogen blev vel modtaget og udkom i flere oplag i den engelske originaludgave, mens den i 2002 udkom i en dansk bearbejdet udgave ved Jakob Balling, Grundtvigs kristendom. Menneskeliv og gudstjeneste.

\section{Samarbejdet udvidedes}

I takt med at arbejdet således skred frem, var der behov for, at vi gjorde os tanker om en mere langsigtet strategi. Økonomisk kunne vi ikke komme videre uden at trække på tilskud fra Aarhus Universitets Forskningsfond, samtidig med at Det Teologiske Fakultet til stadighed var parat til at støtte fra fakultetets ellers stramme budget, når vi fremlagde velmotiverede ansøgninger. Men uanset hvor meget vi således havde lokal opbakning fra ledelsen på fakultetet og fra universitetets rektor, Henning Lehmann, var det indlysende, at sådanne lokale bevillinger måtte suppleres med tilskud udefra. Derfor var det opmuntrende, at Kirkeligt Samfund på Vartov (senere Grundtvigsk Forum) var særdeles imødekommende, ligesom der fra Grundtvig-Selskabet og N.F.S. Grundtvigs Fond blev bevilget tilskud, selv om disse to institutioner kun havde rådighed over begrænsede midler. Det lykkedes derudover heldigvis at opnå yderligere tilskud fra andre institutioner og fonde, således at vi til stadighed kunne bygge oven på det allerede opnåede.

Indledningsfasens iværksætterånd måtte naturligvis gradvist omstøbes, således at det hele fandt plads inden for mere regulerede rammer. Det Teologiske Fakultets sekretariatschef, Hanne Stenbæk, spurgte os, om vi nu var sikre på, at vi kunne samarbejde. Hvis det var tilfældet, tilføjede hun, ville hun råde os til at undlade at udforme et bindende regelsæt, fordi vi derved kunne undgå administrativt besvær og trældom under utallige møder, som alle på universitetet i disse år måtte leve med. Men forudsætningen var rigtignok, understregede Hanne Stenbæk, at vi kunne samar- 
bejde i en atmosfære af kollegial forståelse uden at skulle falde tilbage på juridiske vedtægter.

I 1989 var der blevet afholdt et møde på Sandbjerg Kursuscenter, hvortil vi havde indbudt kolleger fra de relevante fagdiscipliner samt repræsentanter for alle samarbejdsinstitutioner, herunder i særlig grad Kirkeligt Samfund, og Grundtvig-Selskabet samt kolleger fra nabolandene Norge, Sverige, England og Tyskland. En række af de foredrag, der blev holdt, indgik senere i Grundtvig-Selskabets årbog 1989-1990.

Netop samarbejdet med Grundtvig-Selskabet var ganske afgørende. De to væsentligste aktiviteter i selskabet, afholdelsen af et årsmøde og udgivelsen af årbogen, blev fra og med dette tidspunkt forberedt og gennemført i snævert samarbejde med centeret. Det lykkedes at tilrettelægge nogle fyldige bind og så nogenlunde at bevare et acceptabelt antal medlemmer og abonnenter, selv om vi ligesom alle tilsvarende udgivelser af denne type arbejdede imod tidens ugunst. Enkelte af numrene blev særligt vellykkede og efterspurgte. Det gjaldt i særdeleshed årgang 1993, der rummede indlæg, der var blevet fremlagt i forbindelse med en international konference, som blev afholdt i 1992 som led i de arrangementer, der markerede Det Teologiske Fakultets 50-års jubilæum. Emnet var national identitet og internationalt fællesskab, et emne, der netop i disse år var på alles læber efter omvæltningerne i 1989 og borgerkrigen i det tidligere Jugoslavien. Netop de omtvistede relationer mellem national identitet og bestræbelser på fællesskab hen over alle slags grænser var en påtrængende problemstilling hos Grundtvig selv og i hans samtid, og det var ikke mindre presserende i verden omkring os på det tidspunkt, hvor konferencen blev afholdt. Den blev forberedt i samarbejde med Det Danske Kulturinstitut, der efterfølgende udsendte de relevante indlæg som selvstændig publikation, National Identity and International Community, mens årbogen ud over disse bidrag også indeholdt andre indlæg i stil med tidligere årgange. I anledning af 150-året for åbningen af den første folkehøjskole i Rødding blev der i november 1994 organiseret et internationalt symposium på Liselund i Slagelse om folkeoplysning. Blandt deltagerne var personer fra de baltiske lande, USA og andre oversøiske lande, idet man ville markere, at idealerne bag folkehøjskolen havde fundet global udbredelse. Indlæggene fra dette symposium blev publiceret $\mathrm{i}$ en bog, Enlightenment in an international perspective, redigeret af Lilian Zøllner og Anna Marie Andersen, der begge repræsenterede Nornesalen i Ollerup, Center for Folkeoplysning. Da Kø- 
benhavn i 1994 var europæisk kulturby, blev der arrangeret et internationalt møde, der blev afholdt i Grundtvigskirken på Bispebjerg. Det blev gennemført i samarbejde mellem værtskirken, Nornesalen og Grundtvig Centeret.

Et andet emne, der ligeledes fik megen opmærksomhed, var Grundtvigs forhold til den bildende kunst. En særlig plads indtog her Joakim Skovgaards berømte kæmpemaleri, der fremstiller Kristi nedfart til dødsriget, et maleri der netop havde gennemgået en omfattende restaurering. 2001-årbogen rummede en række bidrag, der særligt behandlede Grundtvig i kunsthistorisk belysning og skilte sig derved ud fra de fleste andre årgange. At det lykkedes at indgå i sådanne samarbejdsrelationer, krævede selvsagt en stor arbejdsindsats. Når det lykkedes, skyldtes det ikke mindst Kim Arne Pedersen, der i 1993 var blevet ansat som forskningsmedarbejder, i første omgang på deltid, senere på fuld tid, i kraft af endnu en økonomisk saltvandsindsprøjtning på foranledning af universitetets rektor. Kim Arne Pedersen udførte et påskønnelsesværdigt arbejde med redaktion af årbogen, forberedelse af små møder og store konferencer samt den fortsatte udbygning af et Grundtvigbibliotek. Det bør desuden nævnes, at arbejdet med renskrivning og redaktionel bearbejdelse af manuskripter til årbogen blev til i et samarbejde med en særdeles kompetent sekretær Birgit Winther-Hansen, hvis indskrivning af manuskripter var så vellykket, at de kunne gå direkte til trykning uden fordyrende mellemled. Dette arbejde blev i en senere fase udført lige så kyndigt af Anne-Grethe Jørgensen Dion.

\section{Thodberg og arbejdet med Grundtvigs prædikener}

Uanset hvor meget forberedelse og afholdelse af sådanne arrangementer optog os, var der dog en række ordinære aktiviteter hjemme ved centeret, der også gjorde krav på megen opmærksomhed og desuden forudsatte betydelige økonomiske investeringer. Det væsentligste og mest ambitiøse projekt var udskrift og udgivelse af Grundtvigs holdte prædikener, i modsætning til de prædikenbind, Grundtvig selv havde forberedt til trykt udgivelse. Christian Thodberg havde allerede i 80'erne udsendt en anselig række prædikenbind, årgangene fra Præstø-årene 1819-21 og tillige de første årgange i København fra 1822 til 1838-39, udkommet 1983-1986. Thodberg havde under dette arbejde indledt et frugtbart arbejdsfællesskab 
med en gruppe studerende, der for fleres vedkommende fortsatte, efter at de var blevet kandidater og indsat i præsteembede. Dette arbejde ønskede Thodberg nu at videreføre og havde til brug herfor behov for assistance af to lønnede medarbejdere. Det blev muligt at tilknytte to af de medarbejdere, der havde oparbejdet særlig kompetence i tydningen af Grundtvigs håndskrift, transskription af manuskripterne samt redaktionel forberedelse til udgivelse, sognepræst Jette Holm og cand.theol. Elisabeth Glenthøj. Med nye økonomiske tilskud blev det muligt for Jette Holm at fratræde sit præsteembede og i stedet lade sig ansætte på fuld tid som forskningsmedarbejder, mens Elisabeth Glenthøj foretrak at have deltidsansættelse. Thodberg skrev selv indledning med indførende kommentarer og perspektiveringer til hvert enkelt bind. Efter adskillige års intensivt arbejde kunne arbejdsgruppen under Thodbergs ledelse fra 2003-2007 udsende otte statelige bind, Grundtvigs prædikener i Vartov fra 1839-45 med et afsluttende kommentarbind som det ottende i rækken.

\section{Centerets forskningspublikationer og internationale seminarer}

Ved siden af dette store projekt blev der holdt flere mindre i studiekredse, herunder en om Grundtvig og den tidlige kristne tradition. De bedste af indlæggene fra disse seminarer blev i bearbejdet form trykt i årbogen. Til den kontinuerlige aktivitet hørte også vejledning til udarbejdelse af individuelle studenteropgaver, specialer og emnekredse. Thodberg havde en speciel evne til at inspirere, begejstre og vejlede studerende, så de kastede sig ud i sådanne opgaver med ildhu og ofte nåede til ganske imponerende resultater. Også Kim Arne Pedersen og jeg havde gennem årene temmelig mange vejledninger. Derudover blev der inden for 20 -års perioden opnået en række videnskabelige grader efter udarbejdelse, bedømmelse og forsvar af indleverede afhandlinger. Der var tale om fem licentiat- eller ph.d.-afhandlinger og en disputats. Kim Arne Pedersen opnåede i 1995 licentiatgraden på grundlag af en afhandling om metafysik og tro hos Grundtvig i årene 1812-1815. Henrik Wigh-Poulsen blev tildelt ph.d.-graden på en afhandling om Jakob Knudsen, Kaj Thaning og Grundtvig, udgivet i bearbejdet form som Hjemkomsten og det åbne land. Jakob Knudsens forfatterskab og den grundtvigske realisme (2001). Erik Kelstrup gennemførte et ph.d.-studium om Grundtvigs sandhedsbegreb set i relation til perspekti- 
ver i moderne religionsfilosofi; Anders Holm blev ph.d. på en afhandling om Grundtvig og Kierkegaard, udgivet som bog med titlen To samtidige. Kierkegaards og Grundtvigs kritik af hinanden (2009); Ulrik Overgaard blev i 2009 ph.d. på en afhandling om Grundtvigs skoletanker, analyseret i sammenhæng med udfordringer i grundtvigske skoler i dag. Om de to sidstnævnte projekter bør det nævnes, at de kunne gennemføres økonomisk i kraft af samfinansiering med eksterne institutioner: Anders Holms projekt blev således finansieret med ligelig støtte fra Søren Kierkegaard Forskningscenteret og Grundtvig Centeret, og Ulrik Overgaards projekt blev i vid udstrækning medfinansieret af en række grundtvigske skoleinstitutioner. Regner Birkelund forsvarede i 2008 en doktordisputats om Grundtvigs frihedstanker, Frihed til falles bedste. En oppositionel stemme fra fortiden. Afhandlingen var blevet til efter en mangeårig forskningsindsats og udarbejdet i en proces med tilknytning til Grundtvig Centeret.

Det fortjener at blive omtalt, at individuelle forskere, der ikke ansættelsesmæssigt var knyttet til centeret, men samarbejdede med det, i årenes løb udgav væsentlige afhandlinger med en større eller mindre grad af samvirke med centeret. Dette gælder Helge Grell, der i 1988 var blevet dr.theol. på to store afhandlinger. Efterfølgende opnåede han støtte fra Carlsbergfondet, således at han kunne samle materiale til endnu to bøger, begge om Grundtvigs forhold til England, England og Grundtvig (1993) samt Grundtvig og Oxforderne (1995). Eftersom bøgernes udgivelse helt igennem var finansieret udefra først og fremmest af Carlsbergfondet, kunne forfatteren ikke selv modtage noget provenu ved salg, men lod det i stedet tilfalde Grundtvig Centeret. K.E. Bugge udgav i 2008 bogen Grundtvig og slavesagen (2003), en bog hvis emne og problemstilling i mange henseender foregreb de drøftelser, der på det seneste har fundet sted i anledning af, at det er 100 år siden, Danmark solgte de tre vestindiske øer til USA.

Samtidig med at aktiviteterne i den hjemlige danske sammenhæng således blev udbygget, skete der også en videreførelse og udbygning af de internationale kontakter. I sommeren 1995 blev der afholdt en konference i Chicago, arrangeret af en af de mange amerikanere med danske aner, Daniel F. Martensen. Kontakten med Martensen var kommet i stand året forinden, mens Allchin og jeg var på en forelæsningsrejse til en række amerikanske universiteter, herunder netop Chicago og Grand View College i Des Moines, Iowa, en skole der i sin tid var blevet grundlagt af 
Grundtvigs søn Frederik Lange Grundtvig. Ved konferencen i Chicago blev der holdt foredrag af flere amerikanske Grundtvigkendere, herunder også nogle stykker med dansk baggrund, ligesom flere af de danske og engelske deltagere holdt oplæg. En række af bidragene blev efterfølgende trykt i en ny artikelsamling, der i lighed med den tidligere skulle fremtræde som en samtale mellem danske og internationale kendere, Grundtvig in International Perspective. Studies in the Creativity of Interaction, red. af A.M. Allchin, S.A.J. Bradley, N.A. Hjelm og J.H. Schjørring (2000).

Endnu et væsentligt skridt i bestræbelserne på at opbygge kontakter i andre dele af verden blev foretaget, da der i januar 1999 blev afholdt en international Grundtvigkonference ved Jadavpur University i Calcutta, arrangeret af professor Asoke Bhattacharya. Han havde i årene forud været på forskningsophold i Danmark og tilbød nu at tilrettelægge et seminar ved det universitet (Jadavpur) i Calcutta, hvor han selv var professor. En anselig gruppe danske Grundtvigkendere deltog. Indlæggene blev efterfølgende udgivet i Calcutta i en lille artikelsamling med titlen Education and Development. Proceedings of the Grundtvig International Conference held at Jadavpur University in January 1999 (2003). Konferencen blev i flere henseender en succes, $\mathrm{i}$ en sådan grad at Asoke Bhattacharya følte sig tilskyndet til at følge op med en lignende konference i 2003 og endnu en i 2007. Der var på dette tidspunkt forhåbninger om, at initiativet i Calcutta kunne udvikle sig, således at det blev et forsknings- og undervisningscenter, der rakte ud mod hele Sydøstasien. Disse forhåbninger lod sig imidlertid af forskellige grunde ikke umiddelbart virkeliggøre.

De opmuntrende resultater ude og hjemme førte til, at det i begyndelsen af nullerne lykkedes at skaffe betydelige nye tilskud af eksterne forskningsmidler. Carlsbergfondet bevilgede som personlig anerkendelse af Thodbergs forskningsindsats et anseligt beløb, der satte Thodberg og hans arbejdsgruppe i stand til at videreføre deres udgivelsesprojekt over en flerårig periode. Dette beløb kunne til og med suppleres med et lige så rundeligt tilskud fra Aarhus Universitets Forskningsfond. Disse bevillinger skulle fordeles på tre områder, som vi havde opstillet som øverste prioriteter på vores ønskeliste: dels som nævnt prædikenprojektet, dels en bog, der behandlede Grundtvigs politiske tanker, og endelig et initiativ, der sigtede mod udgivelse af udvalgte skrifter af Grundtvig på engelsk. Til opgaven at skrive om Grundtvig som politiker og hans politiske ideer udpegede vi historikeren Claus Bjørn. Han påtog sig beredvilligt opga- 
ven, da han delte synspunktet, at netop de politiske perspektiver var et underbelyst emneområde i Grundtvigforskningen. Imidlertid blev Claus Bjørn pludseligt syg og døde, da han endnu kun var nået et stykke vej med projektet. Efter nogle forhandlinger kunne vi overtale vores kollega fra fakultetet i Aarhus, Thorkild C. Lyby, til at arbejde videre med det materiale, Claus Bjørn havde efterladt, således at det kunne udgives som bog: Claus Bjørn, Grundtvig som politiker. Udgivet af Thorkild C. Lyby (2007).

Til at varetage den tredje del af projektet, forberedelse af et udvalg af skrifter i engelsk oversættelse, udpegede vi den engelske litteraturhistoriker fra University of York Sidney Arthur James Bradley, der gennem en længere årrække havde leveret en lang række væsentlige bidrag om Grundtvig og den oldengelske digtning, hvor han kunne trække på sin ekspertise inden for netop studiet af "Anglo-Saxon poetry". Bradleys arbejde blev efter mange års indgående forberedelse til den monumentale bog N.F.S. Grundtvig. A Life Recalled. An Anthology of Biographical Source-Texts translated from the Danish and edited by S.A.J. Bradley (2008). De biografiske tekster var baseret på bogen Grundtvigs erindringer - erindringer om Grundtvig udgivet i 1948 af Steen Johansen og Henning Høirup, nyt oplag i 1983. Dette biografiske materiale supplerede Bradley og tilføjede forklarende kommentarer for internationale læsere. Tillige rummer bogen et minileksikon, "Index", på 250 sider, med navne og begreber vedrørende Grundtvig i specifik forstand, men også vedrørende dansk kulturhistorie i det 19. århundrede i videre forstand. Det var Bradleys synspunkt, at det ville være den bedste procedure for udgivelsesprojektet at indlede den planlagte serie med et biografisk bind, eftersom ikke-danske læsere vanskeligt ville kunne komme videre uden et kendskab til netop personen Grundtvig og hans samtid. Af forskellige grunde blev der ikke mulighed for at videreføre projektet under Bradleys ledelse, men ideerne er i stedet efter 2008 taget op under nye forudsætninger af det nye center.

Det nye center og arbejdet med en videnskabelig digital udgave

På dette tidspunkt blev der sat en række sonderinger i gang, der skulle føre frem til en helt ny fase i Grundtvigforskningen, nemlig udgivelsen af Grundtvigs skrifter på videnskabeligt grundlag. Dette arbejde havde baggrund i et længe næret ønske hos ledelsen af Grundtvigsk Forum om 
at skaffe en tilgængelig moderne Grundtvigudgave til veje. Derfor foregik møderne på Vartov med deltagelse af en repræsentativ kreds af Grundtvigforskere. Formandskabet i dette "udredningsudvalg" havde jeg i samarbejde med Henrik Wigh-Poulsen, på daværende tidspunkt akademileder ved Grundtvig-Akademiet på Vartov. Det egentlige arbejde med registrering og katalogisering af Grundtvigs skrifter blev udført af Kim Arne Pedersen, der nu var ansat ved Vartov, en omfattende opgave, tør man roligt sige, som Kim Arne Pedersen kastede sig ud i med stor energi og med anvendelse af sit efterhånden legendariske kendskab til hele Grundtvigs forfatterskab. Drøftelserne i udredningsudvalget blev bragt nogle væsentlige skridt videre i kraft af, at Niels Jørgen Cappelørn kunne bidrage med den erfaring, han havde opnået gennem sit mangeårige arbejde som leder af Søren Kierkegaard Forskningscenteret og dermed også koordinator af den videnskabelige Kierkegaard-udgave. Efter intense rådslagninger gennem talrige møder nåede udvalget omsider frem til en plan, der anbefalede oprettelsen af en Grundtvigportal med henblik på gradvist at give offentligheden adgang til Grundtvigs skrifter i elektronisk version og med videnskabeligt apparat. I den afsluttende fase havde vi stor nytte af, at Marianne Jelved accepterede at træde ind som formand for en bestyrelse. I samarbejde med hende kunne jeg udarbejde en ansøgning om tilskud fra tipsmidler, der skulle skaffe økonomisk grundlag for de indledende aktiviteter, inden det egentlige arbejde med Grundtvigudgaven kunne indledes. Dette tilskud blev opnået, således at midlerne samtidig kunne anvendes som led i markeringen af Grundtvigs 225-års dag i 2008. Med disse beslutninger og tilskud var de væsentligste forudsætninger opfyldt, der kunne bane vej for etableringen af det nye projekt.

Da det nye Grundtvigprojekt blev optaget på finansloven, blev hele rammen for Grundtvigforskning en ganske anden. Der var nu grundlag for at ansætte en leder af det nye center, som fortsat skulle have hjemsted ved Det Teologiske Fakultet i Aarhus. Dermed var der også givet signal om, at de foregående 20 års provisoriske tilstand med ad hoc-løsninger nu kunne afløses af en gylden fremtid med lukrative rammevilkår. 